\begin{tabular}{|l|l|l|l|}
\hline 皿 & Received 14/02/2019 & 咂 & Published 10/04/2019 \\
\hline
\end{tabular}

\title{
Alcohol and Khamr in Fiqh Based on Science Perspective
}

\author{
Rafika Dwi Rahmah MZ \\ Email : rafikadrmz1605@gmail.com
}

Universitas Ahmad Dahlan, Yogyakarta, Indonesia

ABSTRACT

Alcohol and khamr are compounds that we can meet every day but there are still many students and even the general public who do not understand the differences in the halal and prohibition of alcohol and khamr. Departing from this matter, this study aims as a means of education and proves the prohibition and halalness of alcohol and khamr. This article examines the views of science and the Qur'an on the prohibition and halalness of alcohol and khamr with the literature review method with a type of qualitative descriptive research. The results of this study are that khamr in Islam is intoxicating (including liquor, narcotics, psychotropic, and other dangerous drugs) whereas alcohol, not all groups can be used as ingredients for making khamr drinks. Therefore, in science, khamr and alcohol are different. Alcohol has two laws, if it is ethanol, it tends to be haram (prohibited), and other types are still considered to be halal (permitted).

\section{INTRODUCTION}

The problems that occur in this study based on criticism of Islamic education textbooks in the $8^{\text {th }}$ grade of junior high school, in the book that alcohol is forbidden (Ahsan dan Sumiyati, 2017: 213-215). Therefore, there are many misperceptions about the status of halal and haram of alcohol. Even though many food, beverage, cosmetics, and pharmaceutical industries use alcohol as a mixture in their products (Irianto, 2013, and MUI, 2013). In alcohol, the law is different from the law of giving khamr which is clearly haram in the Al-Quran so that all scholars agree that khamr is haram and have an impact on some ulama who disagree about the law of fiqh from alcohol (Jamaludin, Mahyeddin, Salleh, \& Ramli, 2015:967). So that the effort that can be made from these problems is to provide a correct understanding of alcohol and khamr to students and society in fiqh learning with a science perspective, and the effects that can be caused from alcohol and khamr that are haram (Ali Mustapa Yaqub, 2013: 121-125, and Mahmud, 2018:136).

Indeed, in Islam, food, drinks, and daily necessities are arranged in the Qur'an and hadith so that Muslims must be selective in choosing the products of their needs, as mentioned in Bukhari no. 2051 and Muslim no. 1599. The Prophet Muhammad in the hadith describes that Muslims are obliged to choose products that are lawful, good and healthy. The Qur'an clearly states that pigs, khamr, blood, carcasses, 
fangs, and others are absolutely unclean (Muhammad, 2006), but many of Muslims misinterpret between khamr and alcohol so that alcohol included in khamr's illegitimate law (MUI No 11, 2009).

In Indonesia, there are institutions that deal with halal or haram of products, namely the Indonesian Council of Ulama or MUI, but there are still many imported and local products that are commonly used but not registered or not registering halal licenses from MUI (Apriyantono, Anton dan Nurbowo, 2003: 57). It has increasingly become the basis for Muslims in Indonesia that there is a good idea to study the composition of a product before using it. Actually, in Islam, halal and haram differences are very clear, but there is still debate as a result of many developing technologies (Ashar, 2015).

The scientific study of alcohol and khamr that has been done in a manner that is valid by halal guarantee agencies in several Muslim majority countries as harmonization of halal-haram rules reflects the progress of technology, but counseling to students/communities about the differences of halal-haram is still considered unclear. Based on the mentioned fact, this article will analyze alcohol and khamr on fiqh with a science perspective by using the literature review method.

\section{DISCUSSION}

\section{Halal-Haram in Foods and Drinks}

The word halal comes from Arabic which means "permissible." The term halal interpreted as something that can be done according to sharia law (Departemen Agama Islam, 2003: 3). Halal food and drinks are foods that can be consumed in a way that is permitted and purchased (Al-Qardlawi,1994). In the Islamic religion, all food and beverages have the fundamental law of halal and mubah unless it has been mentioned in the Al-Quran and the Hadith if it is unclean, endanger oneself, and religion. The range of food and beverages that are halal is extensive compared to the haram. According to Muhammad Umar Chand (2003) in general, food and drinks divided into three categories, namely: vegetable, animal, and processed products.

Foods and beverages made from vegetable as a whole are lawful unless there are poisons or disrupt human physical and psychological health (Mudhafier and Wibisono, 2004: 45). Animal food and beverages divided into two groups, namely land animals and marine animals. Legal marine animals are different from land animals except grasshoppers, inside (QS. Al Maidah: 3) explain the prohibition of carcasses, blood, pork and those slaughtered in the name other than Allah which only applies to land animals while the bodies of sea animals and grasshoppers are lawful as mentioned in Ibnu Majah no. 3218. Syaikh Al Albani says that this hadith is saheeh (Al-Qur'an interpretation of Azhim, Ibn Kathir, 5/77, Muassasah Qurthubah).

Processed foods and beverages are food and drinks prepared from raw materials with technological processes with additional preservatives or other ingredients (Al-Hafdz, 2007: 184). In this article, it will be more related to vegetable food and processed foods containing natural alcohol or reaction products. Allah gives orders and prohibitions to his servants not without cause food and drinks that are 
haram have a negative effect on our bodies such as alcoholic beverages which cause damage to organs and psychologically (Taufikin, 2015:488).

\section{Alcohol and Khamr According to the Science Perspective}

Based on chemistry, alcohol is an organic compound or hydrocarbon that has an $\mathrm{OH}$ functional group (Monick, 1968: 4). Alcohol has a functional group similar to water, so it is often used as a solvent for many industries (Bohari,1988: 37). Alcohol is obtained from the fermentation process of substances containing carbohydrate compounds such as sugar, honey, wheat, from fruit or tubers (Myers, P.L. and Isralowitz,2011). The type and class of alcohol produced depend on the ingredients and fermentation process (Bae et al., 2007: 310). According to Berraud (2000: 451-454) alcohol (ethanol) can be produced in two ways, namely: 1) the method of petrochemicals (the process of fossil fuels) through the hydration of ethylene. Ethanol produced by hydration is commonly used as feedstock (synthetic material) to produce other chemicals or as a solvent (solvent), and 2) biological methods through fermentation of sugar with yeast (yeast).

Alcohol is made by fermentation from raw materials containing sugar which is quite high in grains (like corn, rice, wheat and barley), tubers (such as potatoes and cassava), fruits (such as grapes, apples, pears, cherry), palm plants (such as sugar palm and coconut), sugar cane and sugar beet, and sugar drops (Gill and Donaghy, 2004: 485-491). Especially for raw materials for grains, before the fermentation process takes place, the ingredients are processed first by soaking them into sprouts, then boiling and processing them into porridge and cooking again (Budak et al., 2014).

The commonly used yeast is saccharomyces cerevisiae. This yeast secretes an enzyme that is used to break down sugars such as glucose and fructose into ethanol and carbon dioxide the length of the fermentation process depends on the material and type of product to be produced (Aidoo, Nout, and Sarkar, 2006: 30-39). A short ripening process (imperfect fermentation) that lasts about 1-2 weeks can provide products with an ethanol content of $3-8 \%$ (Steinkraus, 2002: 23-32). An example is beer products. While a longer curing process (perfect fermentation) that can reach monthly or even annual times such as in winemaking can produce products with an ethanol content of around 7-18\% (Watanabe et al., 1990: 33-38).

The ethanol content produced in fermenting alcoholic beverages usually ranges around $18 \%$ because in general yeast cannot live in environments with ethanol content above 18\%. Produce alcoholic drinks with a higher ethanol content, the distillation process (distillation) is carried out on products produced through the fermentation process (Zheng and Han, 2016: 19-25). The resulting product group is called distilled beverages. Another production method for producing high ethanol drinks is by mixing fermented products with infused products. Examples are port wine and sherry products which belong to the fortified wine group (Wahono et al., 2015: 331-33). For certain products, to produce the desired flavor, you can add certain ingredients such as herbs, fruits, or flavoring ingredients. Alcohol can be divided into several types, namely mono-hydroxy alcohol, and polyhydroxy alcohol. 
Monohydroxy alcohol is an alcohol-containing one hydroxyl group. There are five types of Mohohidroxy alcohol.

Table 1. Type of Monohydroxy Alcohol

\begin{tabular}{|c|c|c|c|c|}
\hline No. & Monohydroxy Alcohol & Formula & Usability & Information \\
\hline 1. & Methanol & $\mathrm{CH}_{3} \mathrm{OH}$ & $\begin{array}{l}\text { Frozen prevention, } \\
\text { fuel, varnish, soap, } \\
\text { etc. }\end{array}$ & $\begin{array}{l}\text { Very toxic is } \\
\text { consumed more } \\
\text { than } 0.01 \%\end{array}$ \\
\hline 2. & Ethanol & $\mathrm{C}_{2} \mathrm{H}_{5} \mathrm{OH}$ & $\begin{array}{l}\text { Alcoholic drinks, } \\
\text { Food (Taste, Color, } \\
\text { Smell), } \\
\text { Parfume, Cosmetics, } \\
\text { Medicines, Solvents, } \\
\text { etc. }\end{array}$ & $\begin{array}{l}\text { High level of } \\
\text { toxicity }\end{array}$ \\
\hline 3. & Propanol & $\mathrm{C}_{3} \mathrm{H}_{8} \mathrm{O}$ & $\begin{array}{l}\begin{array}{l}\text { Chemical industries } \\
\text { (rubber, } \\
\text { mixtures), }\end{array} \\
\text { Antiseptics, } \\
\text { Soap, Detergents, etc. }\end{array}$ & Not consumed \\
\hline 4. & Butanol & $\mathrm{C}_{4} \mathrm{H}_{9} \mathrm{OH}$ & $\begin{array}{lr}\text { Chemical industry } \\
\text { (food, medicine), } \\
\text { solvents, } \\
\text { photography films, } \\
\text { plastics, } \\
\text { cleaners, etc. }\end{array}$ & $\begin{array}{l}\text { The waste is } \\
\text { dangerous for } \\
\text { the environment }\end{array}$ \\
\hline 5. & Pentanol & $\mathrm{C}_{5} \mathrm{H}_{11} \mathrm{OH}$ & $\begin{array}{l}\text { The solvent in the } \\
\text { esterification process }\end{array}$ & very toxic \\
\hline
\end{tabular}

(Adapted from Dzulkifly and Nurul, 2008: 21-22).

Polyhydroxy alcohol is an alcohol molecule with two $\mathrm{OH}$ functional groups on its carbon atom. In general, alcohol in polyhydroxy belongs to diol or glycol groups. The type of alcohol contained in polyhydroxy, namely:

Table 2. Type of Polyhydroxy Alcohol

\begin{tabular}{|l|l|l|l|l|}
\hline No. & Polyhydroxy Alcohol & Formula & Usability & Information \\
\hline 1. & Ethylene glycol & $\mathrm{C}_{2} \mathrm{H}_{6} \mathrm{O}_{2}$ & $\begin{array}{l}\text { Polyester, Plastic } \\
\text { Bottles, Fabric } \\
\text { Industries, etc. }\end{array}$ & $\begin{array}{l}\text { Toxic like } \\
\text { methanol }\end{array}$ \\
\hline 2. & Propylene glycol & $\mathrm{C}_{3} \mathrm{H}_{8} \mathrm{O}_{2}$ & $\begin{array}{l}\text { Cosmetics, } \\
\text { Pharmacy, Food, } \\
\text { Beverages, etc. }\end{array}$ & $\begin{array}{l}\text { Widely used in } \\
\text { cosmetics }\end{array}$ \\
\hline 3. & Glycerol & $\mathrm{C}_{3} \mathrm{H}_{8} \mathrm{O}_{3}$ & $\begin{array}{l}\text { Cosmetics, Pharmacy } \\
\text { (as a sweetener), Ink, } \\
\text { Synthetic Fiber, etc. }\end{array}$ & $\begin{array}{l}\text { Moisturizer in } \\
\text { cosmetics }\end{array}$ \\
\hline 4. & Manitol & $\mathrm{C}_{6} \mathrm{H}_{14} \mathrm{O}_{6}$ & Pharmacy & Medicine \\
\hline 5. & Sorbitol & $\mathrm{C}_{6} \mathrm{H}_{14} \mathrm{O}_{6}$ & Food and Pharmacy. & $\begin{array}{l}\text { Substitute for } \\
\text { sugar for the diet }\end{array}$ \\
\hline
\end{tabular}

(Adapted from Dzulkifly and Nurul, 2008: 23-24) 
From this set of tables alcohol has many benefits, seen from its structure usually methanol (no more than 0.01\%), ethanol (beer 1-6\%, whiskey 20-45\%, and wine 5-20\%) (Suzuki, et al., 2008: 209-223) and butanol contained in various alcoholic beverages but in general, ethanol is most abundant in alcoholic drinks (Hall and Oser, 1965; Che, 2001: 42-43). Some of the alcohols such as pentanol in the table are considered not intoxicating but still fall into the dangerous category so that if the law is consumed it is haram but not because of the alcohol compound but if it is consumed by itself (Hasan, 2014).

In this table, ethanol, besides being used as an alcoholic beverage, also functions as a solvent in pharmaceuticals, cosmetics, and food, so it is necessary to pay attention to ethanol levels in the product to ensure halalness (Majelis Ulama Indonesia No 4 Tahun 2003). Every country has a minimum standard of ethanol concentration that used following the policy or fatwa of each guarantee agency. In Indonesia, the maximum ethanol content used in the product is following the MUI Fatwa No.4 / 2003 namely 1\% and ethanol used is not sourced or mixed from the alcoholic beverage industry (Kurniadi and Frediansyah, 2017 147-160). According to Kourkoutas et al. (2004: 377-397) that high concentrated ethanol can cause sodium channels in the synaptosome of the human brain resulting in physical and psychological disorders that cause death, carrying approximately 28,000 people die each year in the United Kingdom due to alcoholic beverages (McIntosh dan Chick, 2017).

Khamar is a type of food and drink that can affect the soul and mental properties of its users (Shihab, 2013: 200). Based on science khamr, it can also be linked to psychotropic drugs and narcotics so that it is not limited to alcoholic beverages so that khamr is not only limited to alcoholic beverages. Sheikh Taqi Falsafi, in his book Child Between Heredity and Education, quotes Alexis Carrel the Nobel Prize winner in medicine with the book Man the Unknown saying:

"The influence of the mixture (chemical compounds contained by food on the activities of the soul and mind of man is not yet known perfectly. However, there can be no doubt that human feelings influenced by the quality and quantity of food not only in terms of material (physical) but also spiritual (Shihab, 2013: 201)."

Purnomowardhani and Koentjoro, in their research stated that adolescents were the largest group using khamr, the data was collected by the National Narcotics Agency (NNN) until 2006. Musni Umar said that every year in Indonesia the abuse of khamr tended to increase even though socialization of khamr was being carried out in Indonesia (Nurbiyati and Widyatama, 2014: 189).

If alcohol is said to be identical with khamr, then this is very fatal. If it is said that each compound containing the - $\mathrm{OH}$ group is khamr, then this is a very destructive understanding. Because honey itself contains compounds containing the - $\mathrm{OH}$ group. Is it from here that honey is forbidden other than that narcotics and psychotropic drugs are also many that do not have -OH group, but the law is still unclean and entered into the khamr class (Halim et al., 2014: 1176-1190). 
Similarly, if someone says that methanol, ethanol, and butanol are the same as khamr it is also fatal. Methanol, ethanol, butanol are multilevel. Methanol, ethanol, butanol are in alcoholic beverages and can be consumed, but ethanol is not originally a substance that can be consumed (Utina, 2012: 97; Tritama, 2015: 7-9).

\section{Alcohol and Khamr According to Fiqh Perspective}

Based on language, alcohol comes from Arabic, namely "alghol" which means intoxicating or damaging the mind (Sulaiman, 2013: 215-231). Ibn al-'Arabi argues that khamr means closing or being able to close the function of reason and confuse human thought so that it removes sanity (Al-Hasiri, 1993: 31). Imam Nawawi explained that the Prophet Muhammad had forbidden all fruits or intoxicants because they were considered alcoholic drinks according to Saheeh al-Bukhari (X/35, no. 5581), and Saheeh Muslim (IV/2322, no. 3032), Sunan Abi Dawud (X/122, no. 3665), Sunan at-Tirmidzi (III/193, no. 1925), Sunan an-Nasa-i (VIII/298). This prohibition cones on alcoholic beverages produced from the fermentation of young dates, dried dates, honey, grapes and other seeds and fruit (Halim and Salleh, 2012: 6-10).

Although many scholars disagreed about the making of khamr, they agreed that all intoxicants from wine fermentation or not were still illegitimate, if anyone denied it it was considered apostate because it belied the Prophet Muhammad (Othman and Riaz, 2000).

Not all alcohols are khamr but all khamr (in the drink category) contains alcohol. There are still many debates that occur due to the issues of the halal side of the cloud group, academics and even scholars. Debates that often occur can be divided into two groups, namely:

a. Groups that judge that alcohol is as haram as khamr.

b. Group that judges alcohol is sacred because it is different between khamr and alcohol even though the main content of khamr is alcohol.

Muhammad Sa'id al-Suyuti (1999) argues that alcohol is sacred because the origin of a material is sacred unless there is a proposition that proves that the material is unclean (Ibn Taymiyyah, 2005: 158). The form of equating alcohol to khamar is considered irrelevant (al-Qiyas ma'a al-Fariq) and is not justified, because the composition of compounds in alcohol and khamr is different. The alcohol contained in khamr becomes unclean because the khamar is intoxicating, but the alcohol remains different because if it is separated from the khamar, it is said to be sacred as well as the alcohol contained in fruits and alcohol used as a treatment (Al-'Uthaimin, 1991:313; Al-Suyuti, 1994: 84).

Mustafa'Afifi (2013: 22-28) argues that alcohol use is important in industrial needs, especially pharmaceuticals and cosmetics. Alcohol is widely used as a chemical analysis reagent and the product is not intoxicating. The above opinion is also reinforced by the view of the High Priest Abu Hanifa $(150 \mathrm{H})$ that you drink wine if the purpose is not for immorality, the law is not haram, but if you drink it causes 
drunkenness then the law changes to haram ('Athiyyah Shaqr, 2006). Something called haram when intoxicating, but if it is not intoxicating, it is permissible.

Nazih Ahmad argues that the use of prohibited substances such as alcohol in medicine is still not replaced or has not found another alternative so that the law is permissible with certain udzur such as when we eat something that is forbidden in a forced state so that if it does not use it can endanger itself. only until it returns to recovery (Hammad, 2010: 51).

\section{Legal Use of Alcohol}

Based on the views of fiqh and science that have been discussed, it can be interpreted if every liquor is sure to contain alcohol but not all alcohol is liquor. If viewed based on science Alcohol obtained from the process of making khamr will have the same content as khamr so that the law is like the origin of khamr and unclean while alcohol is obtained not through the process of making khamr but is haram consumed if it is toxic (Akta Makanan dan Peraturan-peraturan Kuala Lumpur, 2007).

Soft drinks that are processed or made not for the purpose of producing grapes and having alcohol under the $1 \%$ lawless floor because their purpose is ordinary drinks not for intoxicants meanwhile soft drinks are made with the same intentions and methods as the process of making wine, the same as there is a lot or a little alcohol or distilled alcohol is haram to drink (Tahido, 2005).

Foods, beverages, medicines and cosmetics that contain alcohol return to be like fruits, nuts or cereals and also extracts, or the ointments contained therein occur side by side during the process of making non-odious food or drinks and the law used is not taken through the process of making wine (Zakiah, et al., 2014: 482-486).

\section{CONCLUSION}

Progress in the food technology industry has resulted in increased use of alcohol in the manufacture of food, drinks, medicines and even cosmetics. However, the increase in alcohol use is not in line with the socialization of alcohol use, which invites misunderstandings to the halal law. This is quite a long polemic in Indonesia so that it becomes the cornerstone of the importance of this article, especially this article does not look from one perspective but scientifically. Hopefully in the future the people will be more observant about the halal and illicit goods they buy.

The disadvantage of this article is that it only examines alcohol and religious law in Malaysia and Indonesia, whereas many other countries have fatwah from various halal guarantor institutions that can be used as references. 


\section{REFERENCES}

Abdul Basith Muhammad As-Sayyid, M. Abdul Ghoffar, and M. Yasir Abdul Muthalib. (2006). Pola Makan Rasulullah: Makanan Sehat Berkualitas Menurut Al-Quran dan As-Sunnah. Jakarta: Almahira.

AH Mustafa 'Afifi, MSM Mahyeddin, MK Wati, Y Asming, SOSM Najib. (2013). Consumer Protection of Halal Products in Malaysia. Middle-East Journal of Scientific Research 13, 22-28

Ahsan, M dan Sumiyati. (2017). Pendidikan Agama Islam dan Budi Pekerti. Jakarta: Kementrian Pendidikan dan Kebudayaan, 213-215.

Ahsin w. Al-Hafdz. (2007). Fikih Kesehatan. Jakarta: Amzah.

Aidoo, K.E., Nout, M.R., and Sarkar, P.K., (2006), Occurrence and Function of Yeasts in Asian Indigenous Fermented Foods, FEMS Yeast Research, Vol. 6 No.1, 30-39

Akta Makanan dan Peraturan-peraturan (Pindaan Hingga Januari 2007), Kuala Lumpur: MDC Publishers Sdn. Bhd.

Al- 'Allamah al-Syaikh 'Athiyyah Shaqr (2006). Ahsan al-Kalam fi al-Fatawa wa al-Ahkam. Egypt: Amzah.

Al-Hasiri, Sabib bin Ali. (1993). Al-Khamr (Mekah: no year), 31

Al-Qardlawi, Yusuf. (1994) Al-Halal wa al-Haram fi al-Islam. Al-Maktab al-Islami, Beirut

Ali Mustapa, Yaqub. (2013). Kriteria Halal Haram Untuk Pangan, Obat, dan Kosmetika Menurut AlQuran dan Hadist. Jakarta: Pustaka Firdaus,121-125

Amir, Mahmud. (2017). Kajian Hadist tentang Halal, Haram dan Syubhat. Vol 17 No. 2,136

Apriyantono, Anton dan Nurbowo. (2003). Panduan Belanja dan Konsumsi Halal. Jakarta: Khairul Bayaan, 57

Ashar. (2015) Konsep Khamar dan Narkotika Dalam Al-Qurean dan UU. Jurnal Fenomena, Vol. 7, No. 2.

Bae, K., Shin, K. S., Ryu, H., Kwon, C., and Sohn, H. (2007). Identification and Fermentation Characteristics of Lactic Acid Bacteria Isolated from the Fermentation Broth of Korean Traditional Liquor, Andong-Soju. Korean Journal of Microbiology and Biotechnology, Vol. 35 No. 4, 310 .

Bagian Proyek Sarana dan Prasarana Produk Halal Direktorat Jendral Bimbingan Masyarakat Islam dan Penyelenggaraan Haji, Petunjuk Teknis Pedoman System Produksi Halal (Jakarta: Departemen Agama, 2003: 3).

Berraud, C.. (2000). Production of Highly Concentrated Vinegar in Fed-Batch Culture. Biotechnology Letters, Vol. 22 No. 6, 451-454.

Bohari Mohd Yatim. (1988). Alkohol Sebagai Bahan Kimia dan Kegunaannya dalam Kehidupan, IsuIsu Syariah dan Undang-undang, 37.

Budak, N.H., Aykin, E., Seydim, A.C., Greene, A.K.,vand Guzel-Seydim, Z.B.. (2014). Functional Propertiesvof Vinegar. Journal of Food Science, Vol. 79 No. 5, R757-R764.

C, MIntosh and J, Chick. (2017). Alcohol and the Neurvous System. group.bmj.com.

Dzulkifly Mat Hashim dan Nurul Hayati Abdul Hamid. (2008). Penjenisan Alkohol dan Kesan Penggunaannya Dalam Makanan dan Minuman, Halal Journal, 21-22.

Fadhlan Mudhafier dan Wibisono. 2004. Makanan Halal (Kebutuhan Umat dan Kepentingan Pengusaha). Jakarta: Zakia Press.

Fathul Bari. (1379 H). Ahmad bin 'Ali bin Hajar Al Asqolani Asy Syafi 'i. Darul Ma'rifah.

Gill, J.S. and Donaghy, M., (2004), Variation in theAlcohol Content of a 'Drink'of Wine and Spirit Poured by a Sample of the Scottish Population, Health Education Research, Vol. 19 No. 5, 485491.

Hall, R. L.; Oser, B. L. (1965). Recent progress in the consideration of flavouring ingredients under the food additives amendement. III. Gras substances", Food Technol, 151.

Ibn Taymiyyah. (2005). Majmu 'ah al-Fatawa Ibn al-Taymiyyah. Mansurah: Dar al-Wafa.

Irianto, Koes. (2013). Pencegahan dan Penanggulangan Keracunan Bahan Kimia Berbahaya, 98.

John A. Monick, (1968). Alkohol: Their Chemistry, Properties and Manufacture. USA: Reinhold Book Corporation, 4.

KN. Sofyan Hasan. (2014). Kepastian Hukum Sertifikasi dan Labelisasi Halal Produk Pangan. Jurnal Dinamika Hukum, Vol. 14 No.2 
Kourkoutas, Y., Bekatorou, A., Banat, I. M., Marchant, R., \& Koutinas, A. A. (2004). Immobilization technologies and support materials suitable in alcohol beverages production: a review. Food Microbiology, Vol. 21 No. 4, 377-397.

M. Quraish Shihab. (2013). Wawasan Al-Quran, Tafsir Tematik atas Perbagai Persoalan Umat. Bandun: Mizan.

Bandun: Mizan.
MAA Halim, MMM Salleh, M Kashim, AA Ahmad, N Nordin. (2014). Halal Pharmaceuticals: Legal,

(2013). Wawasan Al-Quran, Tafsir Tematik atas Perbagai Persoalan Umat. Shari'ah Issues and Fatwa of Drug, Gelatine and Alcohol. International Journal of Asian Social Science Vol.4 No.12, 1176-1190.

MAA Halim, MMM Salleh. (2012). The Possibility of Uniformity on Halal Standards in Organization of Islamic countries (OIC) country. World Applied Sciences Journal Vol. 17 No. 17, 6-10.

MA Jamaludin, MMM Salleh, MA Ramli. (2015). Penggunaan Alkohol dalam Penghasilan Produk Minuman dan Makanan menurut Perspektif Fiqh. Prosiding Seminar Fiqh Semasa ISBN 97897-13426-1-9 967.

Majelis Ulama Indonesia. (2013). Fatwah Alkohol, 92

Majelis Ulama Indonesia. (2003). Standarisasi Fatwa Halal No 4

Majelis Ulama Indonesia. (2009). Fatwah Hukum Alkohol No 11.

Muhammad ibn Salih al- 'Uthaimin. (1991). Majmu Fatawa. Riyadh: Darl al-Watan li al- Nasr.

Muhammmad Kurniadi and Andri Frediansyah. (2017). Halal Perspective of Microbial Bioprocess Based-Food Products. Vol 16 No 3, 147-160.

Muhammad Umar Chand. (2003). Halal \& Haram: The Prohibited and the Permitted Foods \& Drinks According to Jewish, Christian and Muslim Scriptures, ed. 4, Kuala Lumpur: A. S. Noordeen.

Muhammad Sa'd al-Suyuti. (1994). Mu'jizt fi-al-Tibb li-alNabi al- 'Arabi. Cairo: Shirkat Maktabat Mustafa al-Babi -al-Halibi.

Myers, P.L. and Isralowitz, R.E. (2011). Alcohol: Health and Medical Issues Today. Oxford: Greenwood Publishing.

Nazih Hammad. (2010). Penggunaan Bahan-Bahan yang Haram dan Najis dalam Makanan dan Obatobatan. Selangor: Al-Hidayah Publication, 51.

Othman, R. and Riaz, M. N. (2000). Alcohol: A Drink/ A Chemical. Halal Consum, Fall Issue. 1

Tafsir Al Qur'an Al 'Azhim, Ibnu Katsir, 5/77. Muassasah Qurthubah.

Taufikin. (2015). Hukum Islam Tentang Minuman Keras Pencegahan dan Penanggulangan Perilaku Minuman Keras di Desa Sidomulyo Keamatan Dempet Kabupaten Demak. Vol 3 No 2, 488.

Tritama, K. T. (2015). Konsumsi alkohol dan pengaruhnya terhadap kesehatan. Majority Vol. 4 No. 8 , 7-9.

Titi Nurbiyati dan Arif Widyatama. (2014). Sosialisasi Bahaya Minuman Beralkohol Bagi Remaja. Vol 3 No 3, 189.

Steinkraus, K.H.. (2002). Fermentations in World Food Processing, Comprehensive Reviews in Food Scienceand Food Safety, Vol. 1 No. 1, 23-32.

Sulaiman, A. A. (2013). An Assessment of The Effects of Alcoholism on Drunkards in Keffi Local Government Area of Nasarawa State, Nigeria: Islamic perspective. European Scientific Journal Vol. 9 No. 2, 215-231.

Suzuki, K., Asano, S., Iijima, K., and Kitamoto, K.. (2008). Sake and Beer Spoilage Lactic Acid Bacteria-A Review. Journal of the Institute of Brewing, Vol. 114 No. 3, 209-223.

Utina, S. S. (2012). Alkohol dan Pengaruhnya Terhadap Kesehatan Mental. Jurnal Health and Sport. Vol. 5 No.2, 97.

Wahono, S. K., Rosyida, V. T., Darsih, C., Pratiwi, D., \& Frediansyah, A. (2015). Optimization of Simultaneous Saccharification and Fermentation Incubation Time Using Cellulose Enzyme for Sugarcane Bagasse on the Second-Generation Bioethanol Production Technology. Energy Procedia, 65, 331-336.

Watanabe, T., Aoki, T., Honda, H., Taya, M. and Kobayashi, T. (1990). Production of Ethanol in Repeated-Batch Fermentation with Membrane-Type Bioreactor. Journal of Fermentation and Bioengineering, Vol. 69 No.1, 33-38. 
Yanggo, Huzaemah Tahido. (2005). Masail Fiqhiyah: Kajian Hukum Islam Kontemporer. Bandung: Angkasa, Kerjasama dengan UIN Jakarta Press.

Zakiah, S., Ishak. H. A., Kassan, H. N. (2014). Understanding the Development of Halal Food Standard: Suggestion for Future Reseach. International journal of social science and humanity, Vol. 4 No. 6, $482-486$.

Zheng, X.W., and Han, B.Z. (2016). Baijiu, Chinese Liquor: History, Classification and Manufacture. Journal of Ethnic Foods, Vol. 3 No.1, 19-25. 